\title{
INSPIREE:
}

INDONESIAN SPORT INNOVATION REVIEW

ISSN 2746-6965 (Online), 2774-2520 (Print)

Journal Homepage: https://inspiree.review/index.php/inspiree

\section{Giakusuki Pada Karate: Analisis Peran Kekuatan Otot Lengan dan Otot Bahu}

d

https://doi.org/10.53905/inspiree.v1i1.5

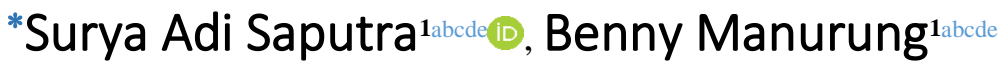

${ }^{1}$ Program Studi Pendidikan Olahraga STKIP Kusuma Negara Jakarta.

Tujuan Penelitian: Untuk mengetahui hubungan kekuatan otot tangan (KOT) dan kekuatan otot bahu (KOB) dengan kemampuan pukulan Giakusuki (PG) peserta ekstrakurikuler karate di SDN 07 Cipinang Melayu.

Metodologi Penelitian: Penelitian ini merupakan penelitian korelasi dan populasi penelitian ini adalah 20 siswa. Instrumen yang digunakan dalam penelitian ini adalah KOT dengan menggunakan dinamometer grib tangan atau handheld dynamometer, untuk survei KOB menggunakan Expanding Dynamometer, untuk survei kayuhan dengan bantalan karet ban dalam.

Hasil Penelitian: Ada hubungan yang signifikan antara KOT dengan kemampuan PG dengan $\mathrm{t}$ hitung 3,163>t tabel 1,729, ada hubungan yang signifikan antara kekuatan otot bahu dengan kemampuan pukulan lurus dengan $t$ hitung 2,874>t tabel 1,729, terdapat Ada hubungan yang signifikan antara KOT, KOB dengan kemampuan PG thitung 5,311>t tabel 3,125

Kesimpulan. Ada hubungan yang signifikan antara KOT, KOB dengan PG peserta ekstrakurikuler karate di SDN 07 Cipinang Melayu.

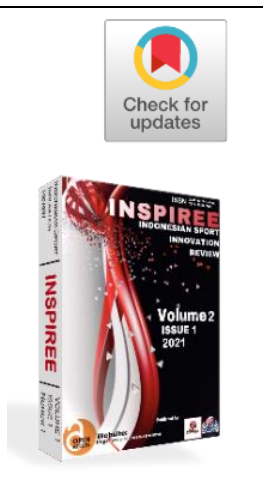

Published:

January 27, 2020

Kata Kunci: giakusuki karate; kekuatan otot tangan; kekuatan otot bahu.

PENDAHULUAN

Karate sudah menjadi olah raga yang populer di masa kini. Seni bela diri dari Jepang ini diciptakan oleh Gichin Funakoshi sebagai salah seorang pendahulu Karate, dimana seorang karate-ka menggunakan tangan kosong untuk melawan dan memukul musuhnya. Ketika mengenal peperangan, beragam teknik berkelahi diciptakan agar bisa memenangkan pertempuran dalam waktu cepat tanpa banyak terluka. Makin lama, ilmu tersebut berkembang menjadi seni tersendiri (M. H. Dos Santos, 2016)

Karate adalah olahraga yang memerlukan kecepatan. Semua gerakan yang cepat adalah gerakan gerakan yang menggunakan sistem anaerobik. Pukulan merupakan salah satu teknik yang dominan dalam olahraga beladiri Karate. Pukulan dalam Karate, terdiri dari beberapa teknik seperti pukulan oitsuki cudan, kizamisuki, giakusuki, dan lain-lain. Dalam hal ini peneliti akan membahas tentang pukulan, pukalan adalah 
mengenakan sesuatu dengan kekuatan tangan. Pukulan sendiri dari karate terdiri dari berbagai macam jenis dan pukulan yang akan dibahas adalah pukulan giakusuki.

Dalam pukulan giakusuki gerakan dari bahu dan lengan sangat dibutuhkan karate-ka. Bahu berperan dalam stabilisasi arah pukulan, sedangkan lengan berperan dalam kekuatan pukulan. Untuk mendapatkan pukulan yang kuat, diperlukan otot yang kuat pula tangan dan kaki selalu digunakan dalam pertandingan karate, sehingga kedua gerakan anggota tubuh ini harus memiliki gerak yang kuat dan cepat agar pukulan maupun tendangan dapat mengenai sasaran dengan tepat (P. H. Purba, 2016).

Pengukuran pukulan dari berbagai aspek sangat penting untuk dilakukan. Hal ini perlu dilakukan untuk memantau perkembangan kemampuan seorang atlit. Selain itu, hasil-hasil pengukuran dapat menjadi bahan untuk merancang program latihan untuk meningkatkan kemampuan atlit. Di sisi lain, informasi kekuatan pukulan seorang atlit dapat mengurangi resiko cidera saat berlatih dengan lawan tanding. Dan untuk menghasilkan dorongan yang kuat, diperlukan KOT yang kuat. KOT yang berfungsi untuk melakukan gerakan ekstensi adalah otot besar berkepala (caput) tiga karena berorigo pada tiga tempat yang berbeda, terletak di sepanjang lengan atas. Dengan metode yang dapat digunakan untuk meningkatkan kekuatan otot.

KOT merupakan unsur penting dalam tubuh manusia seperti yang dikemukakan oleh Rusli Lutan, et al (1988) kekuatan adalah komponen yang sangat penting guna meningkatakn kondisi fisik seseorang secara keseluruhan. Sedangkan menurut Nurhasan (2005) kekuatan adalah kemampuan sekelompok otot dalam menahan beban secara maksimal. Secara sederhana kekuatan dapat diartikan sebagai kemampuan untuk memberikan tenaga terhadap tekanan. Pendapat lain juga dikemukakan oleh Suharno (1981) bahwa kekuatan ialah kemampuan dari otot untuk mengatasi tahanan atau beban dalam menjalankan aktifitas. Kekuatan elastis adalah tipe kekuatan yang sangat diperlukan dimana otot dapat bergerak cepat terhadap suatu tahanan. Kombinasi dari kecepatan kontraksi dan kecepatan gerak disebut power. Daya tahan kekuatan adalah kemampuan otot untuk terus menerus menggunakan daya dalam menghadapi meningkatnya kelelehan. Daya tahan kekuatan adalah kombinasi antara kekuatan dan lamanya gerakan. 
Jenis kekuatan menurut Djoko Pekik Irianto (2004) kekuatan dikelompokan menjadi beberapa jenis antara lain. Kekuatan umum (general strength) : kekuatan yang berhubungan dengan sistem otot secara keseluruhan. Kekuatan khusus (specific strength) : kekuatan otot tertentu yang diperlukan pada gerakan utama suatu cabang olahraga. Kekuatan Eksplosif (Eksplosive strength / power): kemampuan otot atau sekolompok otot untuk mengatasi tahanan dengan gerakan yang cepat, misalnya melompat, melempar, memukul.

Kekuatan Daya Tahan (strength endurance) : kemampuan otot untuk mengatasi tahanan dalam jangka waktu yang lama. Kekuatan maksimum (maximum strength) : kemampuan otot berkontraksi secara maksimal untuk melawan serta memindahkan beban maksimal atau dengan definisi lain tenaga terbesar yang diihasilkan otot untuk berkontraksi. Kekuatan absolut (absolute strength): kemampuan seseorang untuk mengeluarkan kekuatan secara maksimum tanpa memperhatikan berat badannya. Kekuatan relatif (relatif strength) : perbandingan beban yang mampu diangkat dengan berat badan.

Jadi, kekuatan otot merupakan komponen kondisi fisik seseorang yang diciptakan oleh otot atau sekelompok otot yang digunakan tubuh serta melawan tahanan atau beban dalam aktifitas tertentu serta melindungi tubuh dari cidera. Dalam hubungannya dengan olahraga, kekuatan otot merupakan salah satu komponen dasar biomotor yang diperlukan hampir dalam setiap cabang olahraga. Menurut Syaifudin (1997) Kekuatan otot adalah komponen kondisi fisik tentang kemampuanya dalam mempergunakan otot untuk menahan beban sewaktu bekerja. Kekuatan otot merupakan salah satu komponen penting dalam keberhasilan melakukan pukulan, karena KOB membantu pada saat memukul PG. Dalam melakukan pemukulan gerak gerak dorong atau pukulan lebih dominan, saat atlit melakukan gerakan lengan ke belakang sebagai awalan pukulan, otot yang bekerja. Saat lengan bergerak mendorong atau memukul kearah depan atas sekeras mungkin, ada kekuatan ledakan atau power yang adalah kemampuan seseorang untuk mempergunakan kekuatan maksimum yang dikerahkan dalam waktu yang sependek-pendeknya, sedangkan untuk menggerakkan pergelangan tangan mengimbangi gerakan memukul Pada gerakan pukulan saat bahu kanan ditarik kedepan dan lengan dicambukkan lewat atas 
bahu dengan gerak pelurusan keatas depan maka otot yang bekerja sedang untuk menggerakkan lengan memutar kedalam otot.

\section{METODOLOGI PENELITIAN}

\section{Populasi dan Sampel}

Populasi dalam penelitian ini adalah keseluruhan peserta kegiatan ekstrakurikuler Karate-Do di SDN Cipinang Melayu 07 Pagi yang berjumlah 40 Karate-Ka. Pengambilan sampel diambil sebanyak 20 orang siswa, yaitu sebagian dari jumlah keseluruhan peserta ekstrakulikuler Karate-Do di SDN Cipinang Melayu 07 Pagi.

\section{Metodologi dan Instrumen Penelitian}

Teknik pengumpulan data yang digunakan dalam penelitian ini adalah formatformat wawancara, obserfasi, studi dokumen dan juga tes hasil siswa dan pengukuran KOT,KOB dan PG. Serta dengan metode studi dokumen, pengumpulan data dengan menggunakan metode studi dokumen bertujuan untuk menerangkan dan menjelaskan hubungan variabel penelitian. Penelitian ini akan menggambarkan hubungan antara 3 variabel yaitu X1, X2 (variabel bebas) dan Y (variabel terikat).

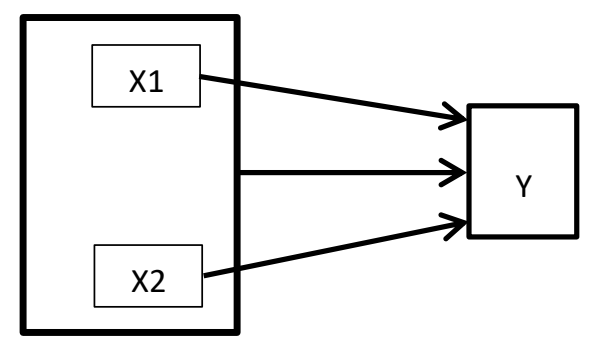

\footnotetext{
Keterangan :

$\mathrm{X} 1$ = Hubungan KOT lengan dengan kemampuan PG

$\mathrm{X} 2$ = Hubungan $\mathrm{KOB}$ dengan kemampuan PG

$\mathrm{Y}=$ Hubungan KOT dan KOB dengan Kemampuan PG
}

Bagan 1. Hubungan antara variabel

Operasional tes pengukuran dalam variabel Kekuatan otot lengan adalah kemampuan seseorang untuk melakukan reaksi, dengan bergerak secepat-cepatnya ke arah sasaran yang telah ditetapkan adanya respon. Selanjtnya Kekuatan otot instrumen tes penilaian bahu adalah kemampuan otot atau sekelompok otot di tangan untuk mengatasi suatu beban atau tahanan dalam menjalankan suatu aktivitas. KOT, KOB diukur dengan hand grib dynamometer satuannya kg. Angka yang diperoleh setelah tester memeras hand grib dynamometer. Dan penilaian Memukul PG adalah merupakan satu parameter penting dalam olahraga beladiri seperti Karate, tinju dan 
lain-lain. Pengukuran pukulan dapat menjadi bahan untuk mendesain program latihan bagi atlit dan mencegah cidera saat latihan.

\section{Statistical analysis}

Analisa data yang digunakan untuk mengetahui hubungan antara KOT dan KOB dengan kemampuan PG Karate digunakan regresi berganda dengan langkah-langkah yang ditempuh dalam analisis regresi menurut Sugiono (2003), adalah sebagai berikut: Membuat persamaan garis regresi dengan tiga prediktor dengan rumus sebagai berikut:

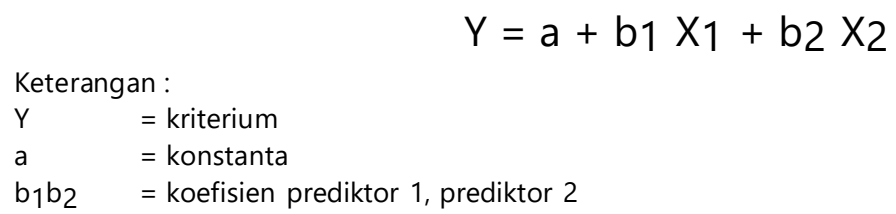

Mencari koefisien korelasi antar kriterium $\mathrm{Y}$ dengan $\mathrm{X}_{1}$, da $\mathrm{n} \mathrm{X}_{2}$, dengan rumus sebagai berikut:

$$
R_{y(1,2)}=\sqrt{\frac{b_{1} \sum x_{1} y+b_{2} \sum x_{2} y}{\sum y^{2}}}
$$

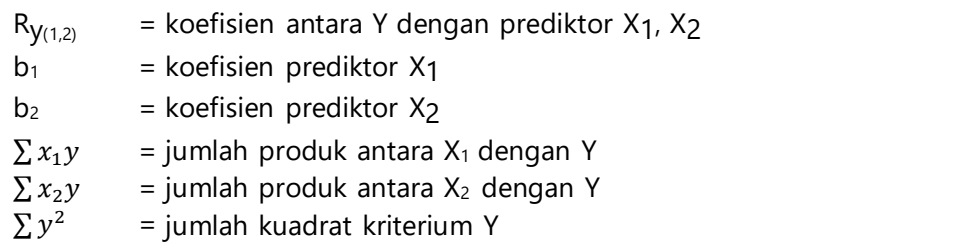

Selanjutnya Uji koefisien regresi secara parsial (t-test) merupakan Analisis ini digunakan untuk mengetahui apakah variable independent secara parsial mempunyai hubungan terhadap variable dependent Jika nilai signifikan $>\alpha(0,05)$, maka keputusannya adalah menerima hipotesis nol (Ho) atau dengan kata lain variabel independent $(x 1, x 2)$ tersebut secara parsial tidak berpengaruh secara signifikan terhadap variabel dependent $(Y)$. Jika nilai signifikan $<\alpha(0,05)$ maka keputusannya adalah menolak hipotesis nol $(\mathrm{Ha})$ atau dengan kata lain variabel independent $(x 1, x 2)$ tersebut secara parsial berpengaruh secara signifikan terhadap variabel independent (Y). adapun rumus uji t sebagai berikut:

$$
t=\frac{r \sqrt{n-1}}{\sqrt{1-r^{2}}}
$$

Keterangan :

$\mathrm{t} \quad=$ Keberartian korelasi

$r \quad=$ Koefisien korelasi

$\mathrm{n} \quad \quad=$ Jumlah testi 
Menguji apakah korelasi itu signifikan atau tidak dengan rumus:

$$
F_{\text {reg }}=\frac{R^{2}(N-m-1)}{m\left(1-R^{2}\right)}
$$

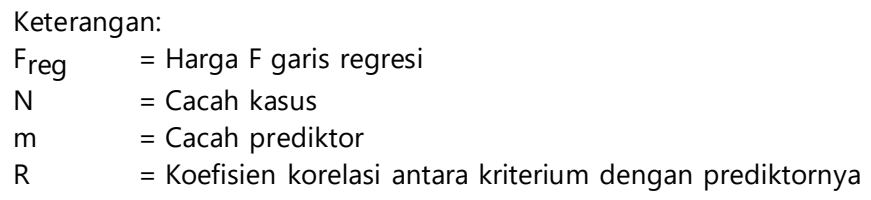

Menentukan sumbangan relatif (SR\%) dan efektif (SE\%)

a) Sumbangan relatif

$$
\mathrm{SR} \%=\frac{\alpha \sum x y}{J K_{\text {reg }}}
$$

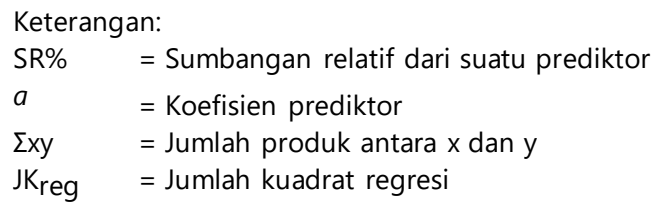

b) Sumbangan efektif

$$
\mathrm{SE} \%=\frac{\alpha \sum x y}{\sum y^{2}}
$$

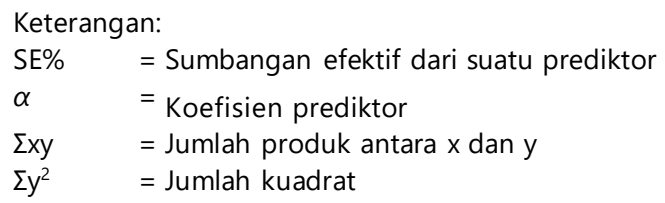

\section{HASIL PENELITIAN}

\section{Deskripsi Data}

Agar lebih jelas mengenai deskripsi data penelitian, berikut akan di deskripsikan data dari masing-masing variabel. Deskripsi data akan menjelaskan nilai maksimum, nilai minimum, standar deviasi, median dan modus, yang kemudian disusun dalam distribusi frekuensi beserta gambar histogramnya. Berikut deskripsi data yang diperoleh dari subyek penelitian:

Tabel 1. Distribusi Frekuensi Variabel Kekuatan Otot Lengan

\begin{tabular}{lcccc}
\hline No & Kelas Interval & Frekuensi & Frekuensi Relatif & Frekuensi Komulatif \\
\hline 1 & $29,5-30,9$ & 5 & $25.00 \%$ & 5 \\
2 & $31,0-32,4$ & 2 & $10.00 \%$ & 7 \\
3 & $32,5-33,9$ & 5 & $25.00 \%$ & 12 \\
4 & $34,0-35,4$ & 3 & $15.00 \%$ & 15 \\
5 & $35,5-36,9$ & 5 & $25.00 \%$ & 20 \\
\hline
\end{tabular}

sumber : Pengolahan Data Peneliti

Apabila digambarkan dalam bentuk histogram, berikut gambar histogram untuk variabel kekuatan otot lengan yang diperoleh. 


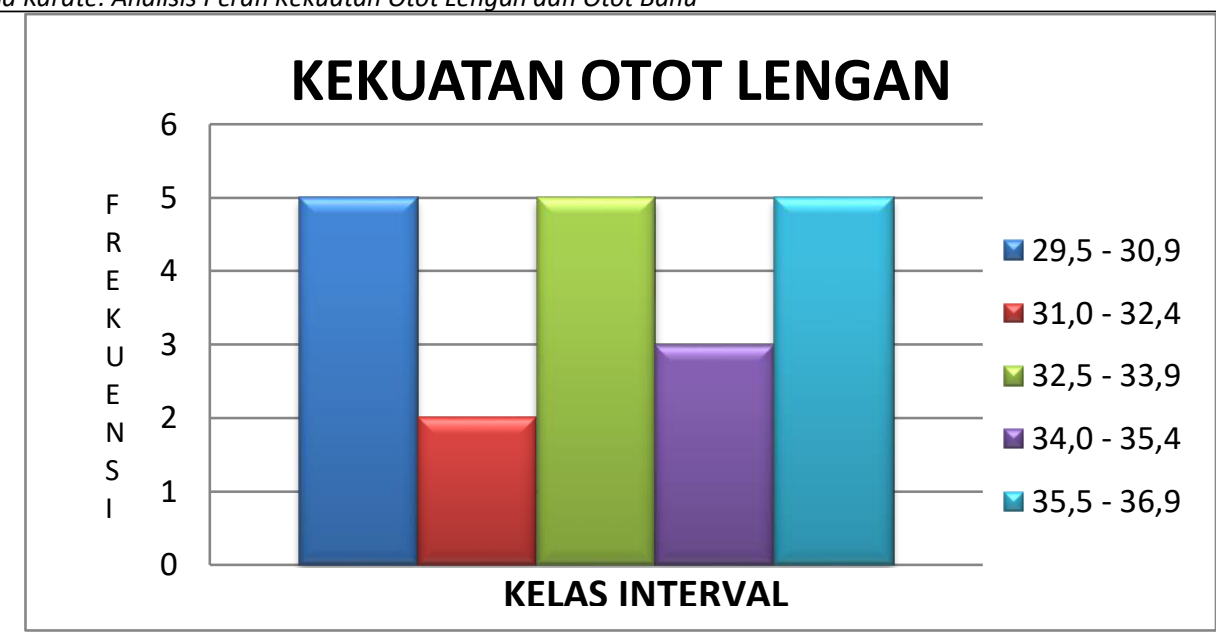

Grafik 1. Histogram Variabel Kekuatan otot lengan

Selanjutnya distribusi frekuensi KOB:

Tabel 2. Distribusi Frekuensi Variabel Kekuatan Otot Bahu

\begin{tabular}{ccccc}
\hline No & Kelas Interval & Frekuensi & $\begin{array}{c}\text { Frekuensi } \\
\text { Relatif }\end{array}$ & $\begin{array}{c}\text { Frekuensi } \\
\text { Komulatif }\end{array}$ \\
\hline 1 & $17-18$ & 2 & $10,00 \%$ & 2 \\
2 & $19-20$ & 6 & $30,00 \%$ & 10 \\
3 & $21-22$ & 2 & $10,00 \%$ & 12 \\
4 & $23-24$ & 2 & $10,00 \%$ & 20 \\
5 & $25-27$ & 8 & $40,00 \%$ & $100,00 \%$ \\
\hline
\end{tabular}

Sumber: Data pengolahan peneliti 2019

Apabila digambarkan dalam bentuk histogram, berikut adalah histogram variabel kekuatan otot lengan yang diperoleh.

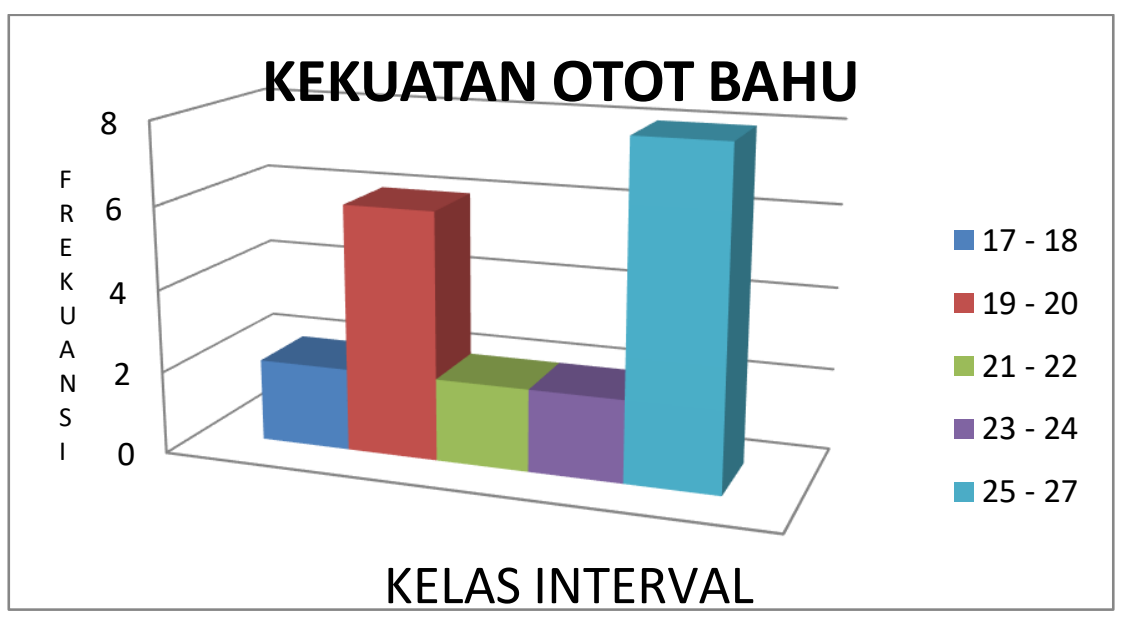

Grafik 2. Histogram Variabel Kekuatan Otot Bahu

Dan terakhir Distribusi Frekuensi Variabel Kemampuan PG. 


\begin{tabular}{lcccc}
\hline No & Kelas Interval & Frekuensi & $\begin{array}{c}\text { Frekuensi } \\
\text { Relatif }\end{array}$ & $\begin{array}{c}\text { Frekuensi } \\
\text { Komulatif }\end{array}$ \\
\hline 1 & $19,0-24,4$ & 1 & $5,00 \%$ & 1 \\
2 & $24,5-29,9$ & 9 & $45,00 \%$ & 10 \\
3 & $30,0-35,4$ & 9 & $45,00 \%$ & 19 \\
4 & $35,5-40,9$ & 0 & $0,00 \%$ & 20 \\
\hline & $41,0-46,4$ & 1 & $5,00 \%$ & $100,00 \%$ \\
\hline
\end{tabular}

Sumber : Data Pengolahan Peneliti 2019

Apabila digambarkan dalam histogram, maka berikut adalah histogram variabel kemampuan PG yang diperoleh.

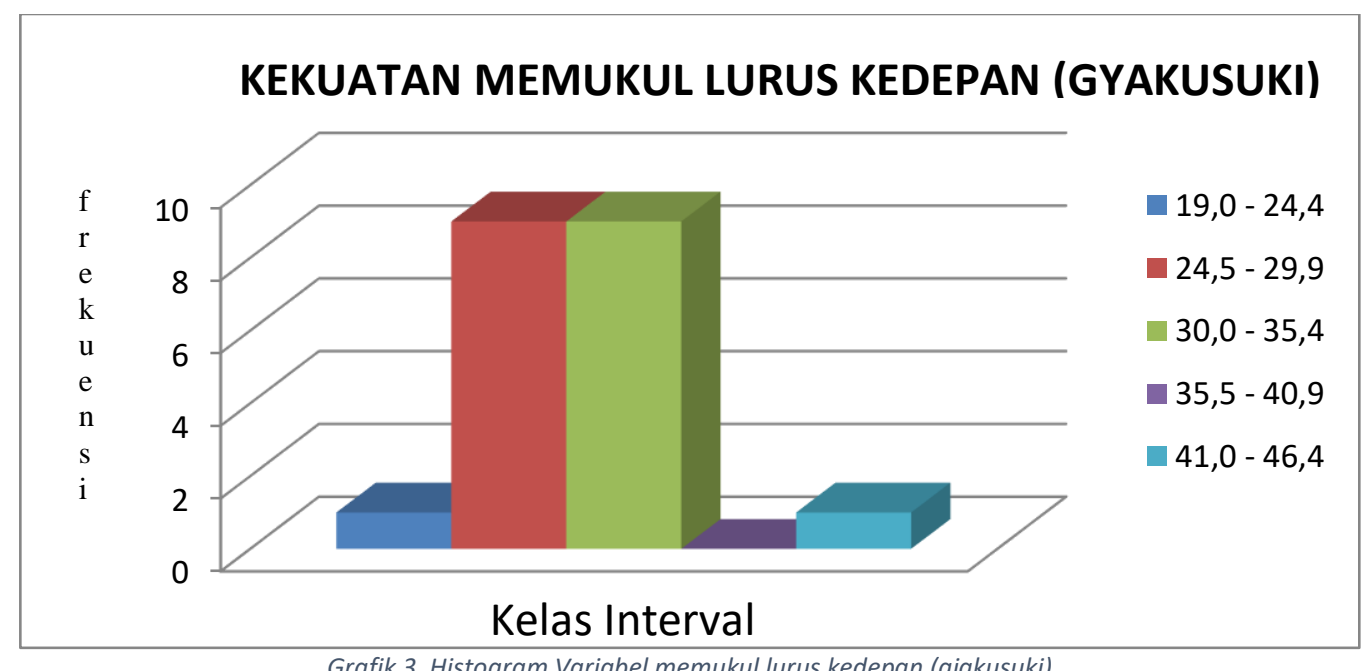

\section{Data Hasil Pengujian Uji Hipotesis}

Untuk hipotesis hubungan antara satu variabel bebas dengan variabel terikat digunakan uji t. Dalam uji ini akan menguji hipotesis nol (Ho) bahwa tidak ada hubungan antara variabel bebas dengan variabel terikat. Untuk menerima atau menolak hipotesis dengan membandingkan harga t perhitungan ( $\left.t_{0}\right)$ dengan harga $\mathrm{t}$ pada tabel $(t t)$. Kriterianya adalah menolak Ho apabila harga to sama atau lebih besar dari harga $t$, dalam hal yang lain terima hipotesis. Uji korelasi sederhana digunakan uji t dari Sudjana (2002: 380). Hasil uji hipotesis untuk hubungan secara sederhana antara variabel kekuatan otot lengan dengan kemampuan memukul lurus kedepan (giakusuki) diperoleh seperti pada tabel di bawah ini :

Grafik 4. Hasil Uji Hubungan Sederhana Variabel Kekuatan Otot Lengan Dengan Kemampuan memukul lurus kedepan (giakusuki)

\begin{tabular}{cccccc}
\hline Korelasi & $\mathbf{r}$ & $\boldsymbol{t}_{\mathbf{0}}$ & $\mathbf{d f}$ & $\boldsymbol{t}_{\boldsymbol{t}}(\boldsymbol{\alpha}=\mathbf{0 , 0 5})$ & Kesimpulan \\
\hline $\mathrm{X}_{1} . \mathrm{Y}$ & 0,598 & 3,163 & 19 & 1,729 & Signifikan \\
\hline Sumber : Pengolahan Data Peneliti & & & & &
\end{tabular}


Dari tabel di atas diperoleh harga $\mathrm{t}_{\text {hitung }}$ hubungan sederhana antara KOT dengan kemampuan PG sebesar 3,163 dan $t_{\text {tabel }}$ sebesar 1,729 . Ternyata harga $t_{\text {hitung }}$ pada hubungan KOT dengan kemampuan PG lebih besar dari harga $t_{\text {tabel, }}$ Dengan demikian dapat ditarik kesimpulan bahwa " Ada hubungan antara KOT dengan kemampuan PG." Dan ini berarti bahwa, hipotesis yang menyatakan tidak ada hubungan yang signifikan antara variabel bebas dengan variabel terikat ditolak.

Hipotesis kedua berbunyi " Ada hubungan antara KOB dengan PG".Untuk hipotesis hubungan antara satu variabel bebas dengan variabel terikat digunakan uji t. Dalam uji ini akan menguji hipotesis nol ( $\mathrm{Ho}$ ) bahwa tidak ada hubungan antara variabel bebas dengan variabel terikat. Untuk menerima atau menolak hipotesis dengan membandingkan harga t perhitungan $\left(t_{0}\right)$ dengan harga t pada tabel $\left(t_{t}\right)$. Kriterianya adalah menolak Ho apabila harga to sama atau lebih besar dari harga $t_{t}$, dalam hal yang lain terima hipotesis.

Uji korelasi sederhana digunakan uji t dari Sudjana (2002: 380). Hasil uji hipotesis untuk hubungan secara sederhana antara variabel KOB dengan kemampuan PG diperoleh seperti pada tabel di bawah ini:

Tabel 4. Hasil Uji Hubungan Sederhana Variabel Kekuatan Otot Bahu Terhadap Kemampuan memukul lurus kedepan (giakusuki)

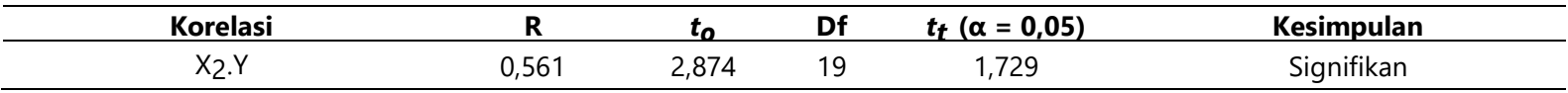

Sumber: Pengolahan Data Peneliti

Dari tabel di atas diperoleh harga $t_{\text {hitung }}$ hubungan sederhana antara KOB dengan kemampuan PG sebesar 2,874 dan $t_{\text {tabel }}$ sebesar 1,729 . Ternyata harga $t_{\text {hitung }}$ pada hubungan KOT dengan kemampuan PG lebih besar dari harga $t_{\text {tabel, }}$, Dengan demikian dapat ditarik kesimpulan bahwa " Ada hubungan antara KOT dengan kemampuan PG." dan ini berarti bahwa, hipotesis yang menyatakan tidak ada hubungan yang signifikan antara variabel bebas dengan variabel terikat ditolak.

Hipotesis ketiga berbunyi "Ada hubungan antara KOT dan KOB, dengan kemampuan PG secara bersama-sama". Untuk uji korelasi ganda digunakan uji $\mathrm{F}$ dari Sudjana, (2002:385). Dalam uji ini akan menguji hipotesis nol (Ho) tidak ada hubungan yang signifikan secara bersama-sama antara variabel bebas dengan variabel terikat. Untuk menerima atau menolak hipotesis nol (Ho) dengan 
Giakusuki Pada Karate: Analisis Peran Kekuatan Otot Lengan dan Otot Bahu

membandingkan harga $\mathrm{F}$ perhitungan $\left(F_{\text {hitung }}\right)$ dengan harga $\mathrm{F}$ pada tabel $\left(F_{\text {tabel }}\right)$.

Kriterianya adalah menolak hipotesis apabila harga $F_{\text {hitung }}$ sama atau lebih besar dari harga $F_{\text {tabel, }}$ dalam hal yang lain terima hipotesis. Hasil uji hipotesis untuk hubungan secara bersama-sama diperoleh seperti tabel di bawah ini:

Tabel 5. Hasil Uji Hubungan Secara Keseluruhan

\begin{tabular}{cccc}
\hline Korelasi Ganda & $\boldsymbol{F}_{\mathbf{0}}$ & $\boldsymbol{F}_{\boldsymbol{t}}(\boldsymbol{\alpha}=\mathbf{0 . 0 5})(\mathbf{2 / 1 9 )}$ & Kesimpulan \\
\hline $\mathrm{X}_{1} \mathrm{X}_{2} . \mathrm{Y}$ & 5,311 & 3,127 & Signifikan \\
\hline
\end{tabular}

Sumber: Pengolahan Data Peneliti, 2019

Dari tabel di atas diperoleh harga $F_{\text {hitung }}$ hubungan secara bersama- sama antara KOT dan KOB dengan kemampuan PG secara bersama-sama sebesar 5,311. Sedangkan harga $F_{t}(\alpha=0.05)(2 / 19)$ sebesar 3,127. Karena harga $F_{\text {hitung }}$ lebih besar dari $F_{\text {tabel }}$ $\left(\mathrm{F}_{\text {hitung }}>\mathrm{F}_{\text {tabel }}\right)$ Dengan demikian dapat ditarik kesimpulan bahwa " Ada hubungan antara KOT dan KOB dengan kemampuan PG secara bersama-sama." maka hipotesis yang menyatakan tidak ada hubungan yang signifikan secara bersama-sama antara variabel bebas dengan variabel terikat ditolak.

\section{PEMBAHASAN}

Berdasarkan hasil perhitungan diperoleh hubungan yang signifikan antara kekuatan otot lengan dan kekuatan otot bahu dengan kemampuan memukul lurus kedepan (giakusuki) sebagai berikut: 1) Ada hubungan antara kekuatan otot lengan dengan kemampuan memukul lurus kedepan (giakusuki) Nilai korelasi sederhana antara kekuatan otot lengan dengan kemampuan memukul lurus kedepan (giakusuki) Kekuatan otot lengan diperlukan untuk melakukan gerakan memukul lurus kedepan (giakusuki). Penggerak utama pada saat melakukan memukul lurus kedepan adalah kekuatan otot lengan dan kekuatan otot bahu. Dengan demikian kekuatan otot lengan memiliki peranan untuk menunjang keberhasilan memukul lurus kedepan (giakusuki). Kekuatan yang dihasilkan mampu memberikan dorongan tangan untuk melakukan pukulan dengan benar. Berdasarkan hasil penelitian dan pengujian hipotesis hubungan variabel kekuatan otot lengan serta kemampuan memukul lurus kedepan (gyakusuki) positif dan signifikan. Nilai korelasi yang diperoleh bernilai positif, ini berarti bahwa semakin baik kekuatan otot lengan seseorang, maka akan semakin baik pula kemampuan memukul lurus kedepan (giakusuki) dalam pencaksilat. 3) Ada hubungan antara kekuatan otot bahu dengan kemampuan memukul lurus kedepan 
(giakusuki) Nilai korelasi sederhana antara kekuatan otot bahu dengan kemampuan memukul lurus kedepan (giakusuki) sebesar 0,561. Berdasar pengujian hipotesis hubungan keduanya signifikan. Nilai korelasi sederhana yang dihasilkan cukup besar, dan berdasar pengujian hipotesis hubungan keduanya signifikan. Kekuatan otot bahu adalah kemampuan sekelompok otot pada bahu untuk melawan beban pada satu usaha, dalam hal ini adalah memukul lurus kekuatan otot bahu secara langsung memberikan dukungan untuk memukul lurus. Karateka melatih kekuatan otot bahu untuk mendapatan hasil memukul lurus kedepan (giakusuki) yang maksimal. Berdasarkan hasil penelitian dan pengujian hipotesis kekuatan otot bahu dengan kemampuan memukul lurus kedepan mempunyai hubungan yang signifikan. Ditandai dengan signifikannya kekuatan otot bahu dengan kemampuan memukul lurus kedepan (giakusuki) pada Karate. 3) Ada hubungan antara kekuatan otot lengan dan kekuatan otot bahu dengan kemampuan memukul lurus kedepan secara bersamasama. Nilai korelasi ganda antara kekuatan otot lengan dan kekuatan otot bahu dengan kemampuan memukul lurus kedepan secara bersama-sama sebesar 0,706. Berdasarkan pengujian hipotesis, ternyata korelasi dari kedua variabel bebas secara bersama-sama dengan kemampuan memukul lurus kedepan signifikan. Hubungan yang diberikan kedua variabel bebas secara bersama-sama dengan kemampuan memukul lurus kedepan sebesar 0,706, dan koefisien determinasi sebesar 0,499. Ini berarti bahwa dari kedua variabel bebas, mempunyai sumbangan sebesar 49,9\%. Tujuan pembentukan teknik pukulan lurus kedepan (giakusuki) adalah untuk mengotomatisasikan gerak kemampuan memukul lurus kedepan. Kemampuan memukul lurus kedepan dapat dibentuk dengan latihan dan pembelajaran secara sistematik, teratur, kontinyu dan berulang-ulang. Tentunya dengan didukung kekuatan otot lengan yang berguna untuk memberikan dorongan pada saat melakukan pukulan lurus kedepan, kemudian dengan kekuatan otot bahu yang digunakan untuk memberikan kekuatan pada lengan sehingga mampu menangkis dan mampu melakukan pukulan lurus kedepan.

Dengan hasil ini mengindikasikan bahwa kekuatan otot lengan dan kekuatan otot bahu mempunyai kontribusi dengan kemampuan memukul lurus kedepan (giakusuki). Apabila kita perhatikan nilai korelasi ganda yang diperoleh yaitu sebesar 0,706 , dan 
koefisien determinasi yang diperoleh sebesar 0,499. Ini berarti bahwa secara keseluruhan atau bersama-sama variable kekuatan otot lengan dan kekuatan otot bahu memberikan kontribusi sebesar 49,9\% dengan kemampuan pukulan lurus kedepan. Pada variabel kekuatan otot lengan, diperoleh hubungan variabel kekuatan otot lengan dengan kemampuan pukulan lurus kedepan sebesar 0,598, dan sumbangan efektif yang diberikan sebesar $21,7 \%$. Pada variabel kekuatan otot bahu diperoleh nilai korelasi sebesar 0,561, dengan sumbangan efektif sebesar $9 \%$. Ternyata sumbangan yang diberikan dari kedua variabel bebas tidak sama, yaitu bahwa variable kekuatan otot lengan memberikan sumbangan yang lebih besar daripada kekuatan otot bahu.

Mengacu pada hasil di atas, maka disarankan agar dalam latihan kemampuan memukul lurus kedepan, perlu melatih kekuatan otot bahu, dengan mendahulukan kekuatan lengan. Hal ini dikarenakan faktor kekuatan otot bahu memberikan kontribusi yang lebih besar dengan kemampuan memukul lurus kedepan. Namun di luar itu masih terdapat banyak faktor lain yang mempunyai kontribusi dengan kemampuan pukulan giakusuki misalnya, kelentukan, panjang lengan, dan lain sebagainya, yaitu sebesar $511,1 \%$.

\section{KESIMPULAN}

Berdasarkan hasil analisis data, pengujian hipotesis dan pembahasan, dapat diambil kesimpulan bahwa: 1) Ada hubungan antara kekuatan otot lengan dengan kemampuan memukul lurus kedepan (giakusuki) pada Karate peserta ekstrakurikuler Karateka SDN Cipinang Melayu 07 Pagi, yang ditunjukkan dengan thitung $>$ ttabel dan p $>0,05$. 2) Ada hubungan antara kekuatan otot bahu dengan kemampuan memukul lurus kedepan (giakusuki) pada Karate peserta ekstrakurikuler SDN Cipinang Melayu 07 Pagi, yang ditunjukkan dengan thitung $>$ ttabel dan $p>0,05$. 3) Ada hubungan antara kekuatan otot lengan dan kekuatan otot bahu dengan kemampuan memukul lurus kedepan (giakusuki) pada Karate peserta ekstrakurikuler SDN Cipinang Melayu 07 Pagi, yang ditunjukkan dengan thitung $>$ ttabel dan $p>0,05$.

\section{UCAPAN TERIMAKASIH}

Penulis dengan ini mengucapkan terima kasih kepada seluruh peserta ekstrakurikuler serta semua orang yang berkontribusi dalam penelitian ini. 


\section{DAFTAR PUSTAKA}

A. W. M. Utomo, F. Y. Wulandari, 2017, Hubungan Antara Kekuatan Otot Tungkai, Perut dan Lengan Terhadap Kecepatan Pukulan Gyaku Tsuki (Study pada Mahasiswa Putra UKM Karate Universitas Negeri Surabaya), Artikel Skripsi, Prodi S1 Pendidikan Kepelatihan Olahraga, Jurusan Pendidikan Kepelatihan Olahraga, Fakultas IImu Keolahragaan, Universitas Negeri Surabaya

Andi Suhendro. (1999). Dasar-dasar Kepelatihan. Jakarta: Universitas Terbuka.

Arikunto, Suharsimi. (1998). Prosedur Penelitian. Yogyakarta: Rineka Cipta.

BNSP. 2006. Ruang Lingkup Penjasorkes. Jakarta: Depdiknas.

Bompa, Tudor. (1994). Theory and Methodology of Training. Toronto: York University.

Dangsina Moeloek \& Arjadino Cokro. (1984). Kesehatan dan Olahraga. Jakarta:

Fakultas. Kedokteran UI.

Djoko Pekik Irianto. (2004). Bugar dan Sehat dengan Berolahraga. Yogyakarta: Andi Yogyakarta.

Harsono. (1988). Panduan Kepelatihan. Jakarta: KONI.

Len Krevitz. (2001). Panduan Lengkap Bugar Total. Jakarta: PT. Grafindo Persada.

M, Nakayama. (1977). Best Karate Comprehensive. Tokyo: Publishing Company.

M. Sajoto, (1995). Pembinaan Kondisi Fisik Dalam olahraga. Semarang: FPOK IKIP

\section{Semarang}

Nurhasan. (2005). Aktivitas Kebugaran. Jakarta: Direktorat Pembinaan Luar Biasa.

P. H. Purba, (2016). Upaya Meningkatkan KecepatanPukulanGyaku Tsuki Chudan

Melalui Bentuk Latihan Variation of Body Drops pada Siswa Putra Ekstrakurikuler Karate SMA Swasta Kristen Immanuel Medan Tahun 2016,Wahana Didaktika

Rusli Lutan. (1988). Belajar Ketrampilan Motorik, Pengantar Teori dan Praktek. Jakarta:

Depdikbud Dirjen Dikti Proyek Pengembangan LPTK.

Saifudin,. (1999). Anatomi Untuk Siswa Perawat. Jakarta: Balai Pustaka.

Sajoto. 1996. Teknik - teknik pukulan dalam karate. Jakarta : Lembaga Pendidikan Tenaga Kependidikan.

Sugiyono. (2003). Statistika Untuk Penelitian. Bandung: CV. Alfabetha.

Suharno HP. (1986). Dasar-dasar Permainan BolaVolley. Yogyakarta: FPOK IKIP Yogyakarta.

Suharno, H. P. (1981). Metodik Melatih Permainan Bolavoli. Yogyakarta: IKIP Yogyakarta. 
Suharno. (1985). Ilmu Kepelatihan Olahraga. Yogyakarta: Yayasan STO.

Suherman, Adang. (2009). Revitalisasi Pengajaran Dalam Pendidikan Jasmani. Bandung: UPI.

Sukadiyanto, 2002. Teori dan Metodologi Melatih Fisik Petenis. Yogyakarta: Fakultas Ilmu Keolahragaan (FIK) Universitas Negeri Yogyakarta UNT

Sukardi. (2003). Metodologi Penelitian Pendidikan Kompetensi dan Prakteknya. Yogyakarta: Bumi Aksara.

Suryobroto, Agus S. (2004). Diklat Sarana dan Prasarana Pendidikan Jasmani. Yogyakarta: FIK UNY.

Syarifudin. (2002). Ilmu Kepelatihan Dasar. Departemen Pendidikan dan Kebudayaan Dirjen Dikti. Jakarta 


\section{LAMPIRAN}

\section{Informasi Tentang Penulis:}

\section{Dr. Surya Adi Saputra, S.Pd, M.Pd, AIFO:}

Email: surya_saputra@stikipkusumanegara.ac.id; Orchid ID: https://orcid.org/0000-00022400-4861; Program Studi Pendidikan Olahraga STKIP Kusuma Negara Jakarta; Alamat: J1 Raya Bogor Km. 24 Cijantung, Jakarta Timur, 13770. DKI Jakarta, Indonesia.

\section{Benny Manurung, S.Pd:}

Email: Bennyman24@gmail.com; Program Studi Pendidikan Olahraga STKIP Kusuma Negara Jakarta; Alamat: Jl Raya Bogor Km. 24 Cijantung, Jakarta Timur, 13770. DKI Jakarta, Indonesia. 